OPEN ACCESS

Edited by:

Dirk Weyhe,

Pius-Hospital, Germany

Reviewed by:

Ulf Gunnarsson,

Umeå University, Sweden

Gabriel Sandblom,

Karolinska Institute (KI), Sweden

Matthias H. Seelig,

Clinics of the Main-Taunus-District,

Germany

*Correspondence:

Stina Öberg

stina.oeberg@gmail.com

Specialty section:

This article was submitted

to Visceral Surgery,

a section of the journal

Frontiers in Surgery

Received: 04 July 2017

Accepted: 29 August 2017

Published: 22 September 2017

Citation:

Öberg S, Andresen K and Rosenberg J (2017) Etiology of Inguinal Hernias:

A Comprehensive Review.

Front. Surg. 4:52.

doi: 10.3389/fsurg.2017.00052

\section{Etiology of Inguinal Hernias: A Comprehensive Review}

\author{
Stina Öberg*, Kristoffer Andresen and Jacob Rosenberg \\ Center for Perioperative Optimization, Department of Surgery, Herlev Hospital, University of Copenhagen, Copenhagen, \\ Denmark
}

Background: The etiology of inguinal hernias remains uncertain even though the lifetime risk of developing an inguinal hernia is $27 \%$ for men and $3 \%$ for women. The aim was to summarize the evidence on hernia etiology, with focus on differences between lateral and medial hernias.

Results: Lateral and medial hernias seem to have common as well as different etiologies. A patent processus vaginalis and increased cumulative mechanical exposure are risk factors for lateral hernias. Patients with medial hernias seem to have a more profoundly altered connective tissue architecture and homeostasis compared with patients with lateral hernias. However, connective tissue alteration may play a role in development of both subtypes. Inguinal hernias have a hereditary component with a complex inheritance pattern, and inguinal hernia susceptible genes have been identified that also are involved in connective tissue homeostasis.

Conclusion: The etiology of lateral and medial hernias are at least partly different, but the final explanations are still lacking on certain areas. Further investigations of inguinal hernia genes may explain the altered connective tissue observed in patients with inguinal hernias. The precise mechanisms why processus vaginalis fails to obliterate in certain patients should also be clarified. Not all patients with a patent processus vaginalis develop a lateral hernia, but increased intraabdominal pressure appears to be a contributing factor.

Keywords: inguinal hernia, etiology, processus vaginalis, connective tissue alteration, risk factors, medial hernia, lateral hernia

\section{INTRODUCTION}

Even though the lifetime risk of developing an inguinal hernia is $27 \%$ for men and $3 \%$ for women (1), the etiology remains uncertain. Inguinal hernias can be subdivided into lateral and medial hernias. Inguinal hernias are almost exclusively lateral in children (2), whereas women and men have both subtypes (3). Lateral hernias are more frequent, but medial hernias have a higher risk to recur after repair $(4,5)$. Lateral and medial hernias are often treated similarly, even though the described differences in age, sex, and recurrence rates imply different etiologies.

The aim was to summarize the evidence on hernia etiology, with focus on differences between lateral and medial hernias.

\section{ANATOMY AND HERNIATION}

The inguinal canal starts at the internal inguinal ring and ends at the superficial ring, containing the spermatic cord in men and the round ligament in women. The integrity of the abdominal wall 
depends on the orientation of the inguinal canal, the transversalis fascia, and the sphincter-like function of the internal ring (6). A hypothesis to the high incidence of inguinal hernias in humans is that the abdominal wall was well constructed when we walked on four extremities, but that the groin area did not have enough time to adopt when we rose to standing on two legs. Lateral hernias arise from the internal inguinal ring, presumably through a patent processus vaginalis (7), and runs in the inguinal canal with or without exit through the superficial ring (8). Medial hernias herniate through a presumably weakened transversalis fascia in the Hesselbach's triangle (8).

\section{RISK FACTORS FOR DEVELOPING A PRIMARY INGUINAL HERNIA}

The risk factors for developing an inguinal hernia can be divided into patient risk factors such as age and sex $(9,10)$, and external risk factors such as physically demanding work $(11,12)$.

\section{Patient Risk Factors}

Risk factors for developing a primary inguinal hernia are male gender and old age $(9,10)$, a patent processus vaginalis (7), systemic connective tissue disorders $(13,14)$, and a low body mass index (BMI) $(10,15)$. Increasing age and low BMI increase the risk of both medial and lateral hernia repairs (12). However, high BMI increases the intraabdominal pressure (16) and also seems to increase the risk of developing a recurrence (4). The relationship probably has a risk of bias since it is easier to detect an inguinal hernia at lower BMI. Constipation does not appear to be a risk factor (17). Researchers have found an association to prostatic hypertrophy (17) but it is uncertain if it truly is a risk factor $(18,19)$.

\section{External Risk Factors}

Smoking increases the risk of recurrence (4), but it is uncertain if it is a risk factor for developing a primary inguinal hernia $(10,12,20)$. An explanation to a relationship between smoking and herniation could be increased collagen degradation and decreased synthesis, shown in human fibroblasts (21). High intraabdominal pressure is also proposed to be a risk factor (22). A database study on 1.5 million individuals showed an increased risk of primary lateral repairs with increased cumulative exposure to daily lifting and standing/walking (11), and by reducing standing/walking from $\geq 6 \mathrm{~h}$ to $<4 \mathrm{~h}$ daily about $30 \%$ of primary lateral hernia repairs can be prevented (12). Intraabdominal pressure increases when coughing, jumping, etc. (16), and the relationship indicates that increased cumulative intraabdominal pressure is involved in lateral hernia formation $(11,12)$, probably through a patent processus vaginalis (23). For medial hernias, which lack a preformed defect, herniation was unaffected by increased cumulative work exposure $(11,12)$. Other factors that can increase the intraabdominal pressure, such as leisure-time physical activity and total load lifted per day, did not increase the risk of neither lateral nor medial repairs (12). Therefore, a certain amount of exposure seems necessary for herniation. Interestingly, increased cumulative exposure to daily lifting and standing/ walking was not risk factors for receiving lateral re-operations (24). Therefore, after surgically closing the preformed defect in form of a patent processus vaginalis, factors other than increased intraabdominal pressure, or cumulative exposure to daily lifting and standing/walking, seem to cause lateral recurrences.

\section{PROCESSUS VAGINALIS}

Patent processus vaginalis is a risk factor for developing lateral hernias. Both persistent smooth muscle cells (25-29) and insufficient release of calcitonin gene-related peptide from the genitofemoral nerve may play a role in failed obliteration (30-32).

\section{The Relationship between a Patent Processus Vaginalis and Herniation}

Processus vaginalis is formed by protrusion of peritoneum during the descensus of the testes, whereafter it should obliterate. Patency of the processus vaginalis and inguinal hernias are strongly correlated (33). The right testis descends later than the left (33), and both persistent processus vaginalis (34) and inguinal hernias are more frequent on the right side in term children $(34,35)$, whereas bilateral hernias are more common in preterm children (35). Also, patent processus vaginalis and inguinal hernias are more common in males (34-36). Asymptomatic patent processus vaginalis is reported in $20 \%$ of patients aged 5 months (34), $9 \%$ at 12 years (37), and $6-19 \%$ of adults $(7,36,38)$. Thus, even though persistent processus vaginalis is a risk factor for developing a lateral hernia (7), it is evident that other factors determine if a hernia actually develops. However, it seems likely that a larger orifice of the proximal annulus would facilitate herniation.

\section{The Role of Smooth Muscle Cells and Molecules in Obliteration of Processus Vaginalis}

Smooth muscle cells are proposed to have a function in testicular descent by "propelling the testis into the scrotum" (39) whereafter apoptosis of the cells may facilitate obliteration of processus vaginalis $(26,40)$. In fact, smooth muscle cells have been found to be more frequent in sacs from inguinal hernias than from hydrocele and undescended testes (25-27), and studies have found insufficient apoptosis (28) and absence of apoptotic nuclei (29) in smooth muscle cells from processus vaginalis. Furthermore, researchers have found smooth muscle cells in a local thickening around the internal ring of lateral hernias (41), which indicates that obliteration of processus vaginalis has been incomplete, and herniation may have occurred through a patent or reopened processus vaginalis (42). Failed apoptosis could be related to the sympathetic nervous system, which enhances smooth muscle growth (43) and maintenance of smooth muscle cells in vitro (44).

A review suggested that androgens indirectly regulate the descent of the testes by acting on the genitofemoral nerve, possibly with release of calcitonin gene-related peptide (45). Several in vitro studies have investigated this peptide (30-32). It induces obliteration of processus vaginalis by transforming epithelial cells to mesenchymal cell phenotype, but calcitonin gene-related 
peptide binding was only directly associated with the mesenchymal fibroblasts (30). Fibroblasts secrete hepatocyte growth factor $(46,47)$, and the effect of the calcitonin gene-related peptide could be mediated by this growth factor, which acts directly on the epithelial cells $(30,31)$. This theory has been tested on hernia sacs, but the peptide only increased the level of the growth factor in some samples (32). It is still unclear if deficient endogenous calcitonin gene-related peptide disrupts obliteration of processus vaginalis (32) or if obliteration is regulated through other mechanisms such as transforming growth factor $\beta-1$, which stimulates fibrosis (48). Detailed investigations in humans have been hindered due to issues with finding proper animal models with patent processus vaginalis (49).

\section{CONNECTIVE TISSUE ALTERATION}

Individuals with inguinal hernias have altered connective tissue compared with controls regarding ratio of collagen fibers, fascia architecture, and level of enzymes involved in connective tissue homeostasis (50-56). When comparing hernia subtypes, patients with medial hernias seem to have a different abdominal fascia architecture and possibly both larger collagen degradation and affected properties of the transversalis fascia due to altered enzyme activity (57-61).

\section{Ratio of Connective Tissue in the Groin}

Table 1 describes fibers and enzymes involved in connective tissue homeostasis. Collagen is the most abundant fiber in connective tissue (62) and the ratio and cross linkage between the thick type 1 and the thin type 3 fiber largely determine the tensile strength and the mechanical stability of connective tissue. A systematic review strongly suggested that patients with inguinal hernias have

TABLE 1 | Connective tissue components.

\section{Fibers}

Collagen

- Type 1

- Type 3

- Type 4

- Type 5

Elastic fiber

elastic fibers together with microfibrils (71). Elastin
comprises of cross-linked tropoelastin (75)

\section{Enzymes}

Lysyl oxidase

Matrix metalloproteinases

- Type 1, 13

- Type 2, 9
Most common collagen type (62) and a thick fiber (68). Often as fibril in tendons (69) and with type 3 in dermis (70)

Fibrillary collagen (thin fiber) (68), often together with type 1 (70). A major component of reticular fiber (assembles in delicate net) in relation to adipocytes and muscle cells and also in the basement membrane (71)

Filamentous network (does not assembles in fibers), in the basement membrane (72)

Minor component of the extracellular matrix. Involved in the fibril-forming of collagen (73) and can be found between type 1 and 3 collagen (74)

Elastin is a protein and the major component of comprises of cross-linked tropoelastin (75)

Catalyze the formation of elastin and cross-links collagen (62)

Zink-dependent enzymes (76)

Degrade collagen 1, 2, and 3 (among others) $(76,77)$

Degrade collagen 1, 4, 5, and elastin (among others) $(76,77)$ a lower collagen 1:3 ratio in the abdominal wall tissue compared with controls (50). Differences between hernia subtypes have been shown (63), but the overall evidence is insufficient (50). One study found significantly lower type 1 and total collagen combined with higher type 3 collagen for lateral hernias compared with controls (64). This would give thinner collagen fibers and may either contribute to hernia formation or be a consequence of the herniation (64). Furthermore, collagen has been shown to decrease in both the transversalis fascia and the rectus sheath with aging (65). In contrary to adults, no alterations in collagen subtypes 1:3 ratios have been observed in children $(66,67)$.

\section{Architecture and Mechanical Properties of Abdominal Fasciae}

Comparing patients with inguinal hernias with controls have revealed both altered architecture of fascia fibers (51) and no difference (52). Comparing hernia subtypes, significantly less collagen and more abundant and disorganized elastic fibers have been shown in patients with medial hernias (57). Young men with medial hernias have also been shown to have thinner rectus sheaths compared with men with lateral hernias and controls (58). A study on mechanical properties of the transversalis fascia found no difference in inguinal hernias compared with controls, and the fascia expansion in medial hernias may solely be a response to the mechanical pressure from the hernia (78). Since cumulative intraabdominal pressure does not increase the risk of primary medial repairs $(11,12)$, it is unclear which factors could promote herniation in the absence of a weakened transversalis fascia.

\section{Enzymes Potentially Involved in Inguinal Hernia Development}

Two types of enzymes have been investigated for their role in inguinal hernia development: matrix metalloproteinases (MMPs), which digest proteins of the extracellular matrix to maintain tissue homeostasis $(76,77)$, and lysyl oxidase, which cross-links collagen and elastin (59). Their influences on hernia development are not fully understood, but an increased activity of MMPs could explain the altered collagen ratios seen in inguinal hernias, and a decreased activity of lysyl oxidase would affect the elastic and mechanical strength of connective tissue. Significantly higher levels of MMP-1, -2 , and -9 in the transversalis fascia have been shown in patients with inguinal hernias versus controls (53). Higher levels of MMP-2 have been shown in patients with medial hernias versus lateral hernias $(60,61)$, which may be due to activation by the cytokine transforming growth factor $\beta-1$ (79). For lysyl oxidase, significantly lower levels of the enzyme combined with higher elastase activity have been shown in medial hernias compared with lateral hernias and controls, and impaired elastic property of the transversalis fascia may especially contribute to medial hernia formation (59). Since the enzyme is copper dependent, lower levels of copper would theoretically lower its activity. Lower levels of copper have been shown in the transversalis fascia of patients with inguinal hernias (54) and when comparing hernia subtypes, both different (80) and equal (54) copper levels have been found. 


\section{Systemic Alteration of Connective Tissue in Patients with Inguinal Hernias}

Inguinal hernias are common in patients with connective tissue disorders, and several studies have investigated if hernia is a local phenomenon of a systemic connective tissue imbalance. Significantly lower collagen subtype 1:3 ratio in skin has been shown for individuals with inguinal hernias $(52,55)$ without any differences between hernia subtypes or MMP-1/13 levels (55). Higher active MMP-2 levels have been found in abdominal skin of patients with medial hernias versus controls, without a difference between hernia subtypes, implying different levels in MMP-modulators (81). Finally, researchers have found a reduced turnover of the interstitial collagen types 3 and 5 and an increased turnover of the basement membrane collagen type 4 in the blood of patients with inguinal hernias, which suggests a systemic imbalance between interstitial- and basement membrane matrices (56). With these systemic findings, altered connective tissue in patients with inguinal hernias must be more than a local response to mechanical pressure from the hernia and thereby play a potential role in the hernia etiology.

\section{GENETICS}

Inguinal hernias are hereditary with a complex multifactorial inheritance pattern $(82,83)$. A nationwide study found that groin hernias are clustered in families, which was most prominent for daughters to mothers that had undergone groin hernia surgery (84). Family specific mutations have been identified in a family with lateral and medial hernias through several generations (85). Generalizable mutations for patients with inguinal hernia have been investigated (86-89), and researchers have recently found four inguinal hernia susceptible loci that seem to be involved in connective tissue homeostasis (90).

\section{DISCUSSION}

Lateral and medial hernias seem to have both common and different etiologies, and the risk factors are summarized in Table 2. A patent processus vaginalis and increased cumulative mechanical exposure are risk factors for lateral hernias. Medial hernias seem to have a more profoundly altered connective tissue architecture and homeostasis compared with lateral hernias. However, altered collagen ratios are seen for both hernia types in adults, and combined with the peak prevalence of hernias observed late in life, connective tissue alterations may very well play a role in development of both subtypes. Furthermore, inguinal hernias have a hereditary component with a complex inheritance pattern, and inguinal hernia susceptible genes have been identified that also are involved in connective tissue homeostasis.

\section{Prevention of a Primary Inguinal Hernia}

We lack diagnostic tools that can predict who will develop an inguinal hernia. Even though gene tests may be used in the future to predict who is at risk, surgical repair of an asymptomatic inguinal hernia may cause more harm than benefit since $10-12 \%$ of patients develop chronic groin pain after operation (91, 92). Laparoscopic repairs seem most promising regarding chronic pain (93), but the difference between laparoscopic- and the Lichtenstein repair seems to equalize after 3-4 years $(94,95)$. Gene tests are thereby only indicated if the chronic pain rate can be lowered after surgery. Even though some professions increase the risk of lateral hernia repairs $(11,12)$, there is no need to discuss

TABLE 2 | Possible etiological factors.

\begin{tabular}{|c|c|c|c|c|}
\hline & $\begin{array}{l}\text { Lateral } \\
\text { hernia }\end{array}$ & $\begin{array}{l}\text { Medial } \\
\text { hernia }\end{array}$ & Results & Reference \\
\hline \multicolumn{5}{|l|}{ External risk factors } \\
\hline High intraabdominal pressure & + & - & $\begin{array}{l}\text { Increase cumulative occupational mechanical exposure increase the risk of lateral } \\
\text { hernia repairs, but not lateral re-operations }\end{array}$ & $(11,12,24)$ \\
\hline Smoking & $?$ & $?$ & May theoretically increase herniation, but this has not been confirmed & $(10,12,20,21)$ \\
\hline \multicolumn{5}{|l|}{ Patient risk factors } \\
\hline Age & + & + & Increasing age increase the risk of both lateral- and medial repairs & $(9,10,12)$ \\
\hline Connective tissue alteration & + & + & $\begin{array}{l}\text { Both medial and lateral hernias have altered connective tissue compared with } \\
\text { controls. Medial hernias seem to have a more profound alteration }\end{array}$ & $(50-61)$ \\
\hline Connective tissue disorders & + & + & $\begin{array}{l}\text { This is a shown risk factor for inguinal hernias, but studies have not subdivided } \\
\text { the results on hernia type }\end{array}$ & $(13,14)$ \\
\hline Constipation & - & - & Does not appear to be a risk factor & $(17)$ \\
\hline Genetics & + & + & $\begin{array}{l}\text { Gene mutations are reported for both hernia types, and generalizable mutations } \\
\text { for inguinal hernias are possibly identified }\end{array}$ & $(82-90)$ \\
\hline Low body mass index (BMI) & + & + & A higher $\mathrm{BMI}$ is a protective factor & $(10,12,15)$ \\
\hline Male gender & + & + & $\begin{array}{l}\text { Studies report male gender as a risk factor for inguinal hernias, without } \\
\text { subdividing the results on hernia type }\end{array}$ & $(9,10)$ \\
\hline Patent processus vaginalis & + & - & $\begin{array}{l}\text { A risk factor, but not all patients with a patent processus vaginalis develop } \\
\text { a lateral hernia. The exact mechanism why processus vaginalis fails } \\
\text { to obliterate is not established }\end{array}$ & $\begin{array}{l}(7,25-32,34 \\
36-38)\end{array}$ \\
\hline Prostatic hypertrophy & $?$ & $?$ & A weak association has been found & $(17-19)$ \\
\hline
\end{tabular}

+, a risk factor; -, not a risk factor; ?, unknown if it is a risk factor. 
inguinal hernias in employment counseling since many will never develop a hernia. However, if a drug was developed that could close processus vaginalis, it should specifically be considered for individuals with a physically demanding job or for patients identified at risk by gene analysis. Therefore, further research on a potential role of calcitonin gene-related peptide deficiency and/ or other mediators is warranted.

\section{Incorporation of Hernia Etiology in Precision-Based Medicine}

The definition of precision-based medicine is to "seek to improve stratification and timing of preventive and therapeutic measures by utilizing biological information and biomarkers on the level of molecular disease pathways, genetics, proteomics as well as metabolomics" (96). Today, we lack diagnostic tests that allow incorporation of the etiology into the concept of precision-based medicine. If biomarker tests could reveal contributing factors to hernia development such as disturbances in the collagen profile, or properly map the gene profile for medial, lateral, bilateral, and recurrent inguinal hernias, then the possibilities for tailored surgery would expand.

Surgical techniques are needed that lower the chronic pain rate after inguinal hernia surgery, and based on the differences in the etiology, tailored surgery for the two hernia subtypes should be considered. One way to lower chronic pain might be to leave less material in the groin, which can be accomplished by using absorbable meshes or by performing sutured repairs.

It is important that absorbable meshes are replaced by new connective tissue to prevent recurrences and these meshes should probably only be considered for lateral hernias (97). However, two systematic reviews have shown no difference in the chronic pain rate between absorbable and permanent meshes, but there were insufficient studies to make a solid conclusion $(97,98)$.

Regarding performing sutured repairs, guidelines have discussed if it would be beneficial for young patients with lateral hernias $(94,99)$ since younger individuals have a higher risk of developing chronic postoperative pain $(100,101)$. A recent study showed that 18 - to 29 -year-old males had a significantly lower cumulated re-operation rate after sutured repair compared with 30- to 99-year-old males (102). It is unclear if sutured repairs actually lower the chronic pain rate in this group, but if that would be the case, sutured repairs could be a valid alternative for young men with lateral hernias.

Permanent meshes seem essential for patients with medial hernias due to the more profound connective tissue alteration.

\section{REFERENCES}

1. Primatesta P, Goldacre MJ. Inguinal hernia repair: incidence of elective and emergency surgery, readmission and mortality. Int J Epidemiol (1996) 25:835-9. doi:10.1093/ije/25.4.835

2. Ein SH, Njere I, Ein A. Six thousand three hundred sixty-one pediatric inguinal hernias: a 35-year review. J Pediatr Surg (2006) 41:980-6. doi:10.1016/j. jpedsurg.2005.11.073

3. Nilsson H, Stylianidis G, Haapamaki M, Nilsson E, Nordin P. Mortality after groin hernia surgery. Ann Surg (2007) 245:656-60. doi:10.1097/01. sla.0000251364.32698.4b
Animal studies have assessed the effect of adding stem cells to meshes with somewhat promising results $(103,104)$. Hopefully, stem cell-coated meshes could be a method to lower the recurrence rate after medial hernia repairs, and perhaps be considered for individuals with a family history of inguinal hernias due to the increased risk of earlier recurrences (82).

\section{Clinical Perspective}

Based on this review, we can answer some of the questions frequently posed by patients. Could the patient have prevented the inguinal hernia? The simple answer is no, unless they have a lateral hernia and a physically demanding job $(11,12)$, but the increased risk disappears after repair (24). Patients might also ask if training of the abdominal wall can prevent a primary hernia or lower the risk of a recurrence. Data are lacking to support this, but very skinny patients can slightly increase their BMI to reduce the risk of a primary hernia to occur $(10,12,15)$, and patients with a high BMI should lose some weight to prevent a recurrence (4). About $11 \%$ of patients with a primary inguinal hernia will have a contralateral repair within 10 years (105). A question surgeons may ask is if we should operate bilaterally instantly. Due to the $10-12 \%$ risk of developing chronic pain, the answer is no. However, future biomarker tests may change this.

\section{Conclusion}

Medial and lateral hernias both have common and different etiologies. Risk factors to develop both lateral and medial hernias are older age, a low BMI, and gene mutations. Even though connective tissue alteration is confirmed in both hernia subtypes, medial hernias appear to have a more profound alteration. Patent processus vaginalis and increased cumulative occupational mechanical exposure are risk factors to develop lateral hernias.

\section{AUTHOR CONTRIBUTIONS}

SÖ contributed substantially to the conception and design of the work, the acquisition and interpretation of data, and drafted the work. KA and JR contributed substantially to the conception and design of the work, the interpretation of data, and revised the work critically for important intellectual content. All authors have approved the final version to be published and have agreed to be accountable for all aspects of the work in ensuring that questions related to the accuracy or integrity of any part of the work are appropriately investigated and resolved.

4. Burcharth J, Pommergaard HC, Bisgaard T, Rosenberg J. Patient-related risk factors for recurrence after inguinal hernia repair: a systematic review and meta-analysis of observational studies. Surg Innov (2015) 22:303-17. doi:10.1177/1553350614552731

5. BurcharthJ,AndresenK, PommergaardHC, BisgaardT, RosenbergJ. Recurrence patterns of direct and indirect inguinal hernias in a nationwide population in Denmark. Surgery (2014) 155:173-7. doi:10.1016/j.surg.2013.06.006

6. Schumpelick V, Treutner KH, Arlt G. Inguinal hernia repair in adults. Lancet (1994) 344:375-9. doi:10.1016/S0140-6736(94)91404-4

7. van Veen RN, van Wessem KJ, Halm JA, Simons MP, Plaisier PW, Jeekel J, et al. Patent processus vaginalis in the adult as a risk factor for the occurrence 
of indirect inguinal hernia. Surg Endosc (2007) 21:202-5. doi:10.1007/ s00464-006-0012-9

8. Rutkow IM, Robbins AW. Classification systems and groin hernias. Surg Clin North Am (1998) 78:1117-27, viii. doi:10.1016/S0039-6109(05)70373-X

9. Burcharth J, Pedersen M, Bisgaard T, Pedersen C, Rosenberg J. Nationwide prevalence of groin hernia repair. PLoS One (2013) 8:e54367. doi:10.1371/ journal.pone. 0054367

10. Ruhl CE, Everhart JE. Risk factors for inguinal hernia among adults in the US population. Am J Epidemiol (2007) 165:1154-61. doi:10.1093/aje/ kwm011

11. Vad MV, Frost P, Bay-Nielsen M, Svendsen SW. Impact of occupational mechanical exposures on risk of lateral and medial inguinal hernia requiring surgical repair. Occup Environ Med (2012) 69:802-9. doi:10.1136/ oemed-2012-100787

12. Vad MV, Frost P, Rosenberg J, Andersen JH, Svendsen SW. Inguinal hernia repair among men in relation to occupational mechanical exposures and lifestyle factors: a longitudinal study. Occup Environ Med (2017). doi:10.1136/ oemed-2016-104160

13. Liem MS, van der Graaf $Y$, Beemer FA, van Vroonhoven TJ. Increased risk for inguinal hernia in patients with Ehlers-Danlos syndrome. Surgery (1997) 122:114-5. doi:10.1016/S0039-6060(97)90273-7

14. Ringpfeil F. Selected disorders of connective tissue: pseudoxanthoma elasticum, cutis laxa, and lipoid proteinosis. Clin Dermatol (2005) 23:41-6. doi:10.1016/j.clindermatol.2004.09.006

15. Rosemar A, Angeras U, Rosengren A. Body mass index and groin hernia: a 34-year follow-up study in Swedish men. Ann Surg (2008) 247:1064-8. doi:10.1097/SLA.0b013e31816b4399

16. Cobb WS, Burns JM, Kercher KW, Matthews BD, James Norton H, Todd Heniford B. Normal intraabdominal pressure in healthy adults. J Surg Res (2005) 129:231-5. doi:10.1016/j.jss.2005.06.015

17. Abramson JH, Gofin J, Hopp C, Makler A, Epstein LM. The epidemiology of inguinal hernia. A survey in western Jerusalem. J Epidemiol Community Health (1978) 32:59-67. doi:10.1136/jech.32.1.59

18. Reis RB, Rodrigues Neto AA, Reis LO, Machado RD, Kaplan S. Correlation between the presence of inguinal hernia and the intensity of lower urinary tract symptoms. Acta Cir Bras (2011) 26(Suppl 2):125-8. doi:10.1590/ S0102-86502011000800023

19. Koskimaki J, Hakama M, Huhtala H, Tammela TL. Association of nonurological diseases with lower urinary tract symptoms. Scand J Urol Nephrol (2001) 35:377-81. doi:10.1080/003655901753224431

20. Lau H, Fang C, Yuen WK, Patil NG. Risk factors for inguinal hernia in adult males: a case-control study. Surgery (2007) 141:262-6. doi:10.1016/j. surg.2006.04.014

21. Yin L, Morita A, Tsuji T. Alterations of extracellular matrix induced by tobacco smoke extract. Arch Dermatol Res (2000) 292:188-94. doi:10.1007/ s004030050476

22. Abrahamson J. Etiology and pathophysiology of primary and recurrent groin hernia formation. Surg Clin North Am (1998) 78:953-72, vi. doi:10.1016/ S0039-6109(05)70364-9

23. Svendsen SW, Frost P, Vad MV, Andersen JH. Risk and prognosis of inguinal hernia in relation to occupational mechanical exposures - a systematic review of the epidemiologic evidence. Scand J Work Environ Health (2013) 39:5-26. doi:10.5271/sjweh.3305

24. Vad MV, Frost P, Svendsen SW. Occupational mechanical exposures and reoperation after first-time inguinal hernia repair: a prognosis study in a male cohort. Hernia (2015) 19:893-900. doi:10.1007/s10029-014-1339-0

25. Tanyel FC, Dagdeviren A, Muftuoglu S, Gursoy MH, Yuruker S, Buyukpamukcu N. Inguinal hernia revisited through comparative evaluation of peritoneum, processus vaginalis, and sacs obtained from children with hernia, hydrocele, and undescended testis. J Pediatr Surg (1999) 34:552-5. doi:10.1016/S0022-3468(99)90071-4

26. Tanyel FC, Talim B, Kale G, Boyokpamukcu N. Differences in the morphology of the processus vaginalis with sex and underlying disease condition. Pathol Res Pract (2000) 196:767-70. doi:10.1016/S0344-0338(00)80109-0

27. Picarro C, Tatsuo ES, Amaral VF, Gomez RS, Cruzeiro PC, Lanna JC. Morphological comparison of processus vaginalis from boys with undescended testis and hernia sacs from boys with inguinal hernia. Eur J Pediatr $\operatorname{Surg}$ (2009) 19:145-7. doi:10.1055/s-0029-1202258
28. Mouravas VK, Koletsa T, Sfougaris DK, Philippopoulos A, Petropoulos AS, Zavitsanakis A, et al. Smooth muscle cell differentiation in the processus vaginalis of children with hernia or hydrocele. Hernia (2010) 14:187-91. doi:10.1007/s10029-009-0588-9

29. Tanyel FC, Erdem S, Buyukpamukcu N, Tan E. Smooth muscle within incomplete obliterations of processus vaginalis lacks apoptotic nuclei. Urol Int (2002) 69:42-5. doi:10.1159/000064359

30. Hutson JM, Albano FR, Paxton G, Sugita Y, Connor R, Clarnette TD, et al. In vitro fusion of human inguinal hernia with associated epithelial transformation. Cells Tissues Organs (2000) 166:249-58. doi:10.1159/ 000016738

31. Cook BJ, Hasthorpe S, Hutson JM. Fusion of childhood inguinal hernia induced by HGF and CGRP via an epithelial transition. J Pediatr Surg (2000) 35:77-81. doi:10.1016/S0022-3468(00)80018-4

32. Ting AY, Huynh J, Farmer P, Yong EX, Hasthorpe S, Fosang A, et al. The role of hepatocyte growth factor in the humoral regulation of inguinal hernia closure. J Pediatr Surg (2005) 40:1865-8. doi:10.1016/j.jpedsurg. 2005.08.044

33. Kapur P, Caty MG, Glick PL. Pediatric hernias and hydroceles. Pediatr Clin North Am (1998) 45:773-89. doi:10.1016/S0031-3955(05)70044-4

34. Weaver KL, Poola AS, Gould JL, Sharp SW, St Peter SD, Holcomb GW III. The risk of developing a symptomatic inguinal hernia in children with an asymptomatic patent processus vaginalis. J Pediatr Surg (2017) 52:60-4. doi:10.1016/j.jpedsurg.2016.10.018

35. Burgmeier C, Dreyhaupt J, Schier F. Gender-related differences of inguinal hernia and asymptomatic patent processus vaginalis in term and preterm infants. J Pediatr Surg (2015) 50:478-80. doi:10.1016/j.jpedsurg.2014.08.015

36. van Wessem KJ, Simons MP, Plaisier PW, Lange JF. The etiology of indirect inguinal hernias: congenital and/or acquired? Hernia (2003) 7:76-9. doi:10.1007/s10029-002-0108-7

37. Centeno-Wolf N, Mircea L, Sanchez O, Genin B, Lironi A, Chardot C, et al. Long-term outcome of children with patent processus vaginalis incidentally diagnosed by laparoscopy. J Pediatr Surg (2015) 50:1898-902. doi:10.1016/j. jpedsurg.2015.07.001

38. Lee DH, Jung HB, Chung MS, Lee SH, Chung BH. Patent processus vaginalis in adults who underwent robot-assisted laparoscopic radical prostatectomy: predictive signs of postoperative inguinal hernia in the internal inguinal floor. Int J Urol (2013) 20:177-82. doi:10.1111/j.1442-2042.2012.03118.x

39. Tanyel FC. A reevaluation of the mechanism of testicular descent: reasons for failed descent or ascent. J Pediatr Surg (2000) 35:1147-9. doi:10.1016/ S0022-3468(00)70059-5

40. Tanyel FC, Muftuoglu S, Dagdeviren A, Kaymaz FF, Buyukpamukcu N. Myofibroblasts defined by electron microscopy suggest the dedifferentiation of smooth muscle within the sac walls associated with congenital inguinal hernia. BJU Int (2001) 87:251-5. doi:10.1046/j.1464-410x.2001.02028.x

41. Jiang ZP, Yang B, Wen LQ, Zhang YC, Lai DM, Li YR, et al. The etiology of indirect inguinal hernia in adults: congenital or acquired? Hernia (2015) 19:697-701. doi:10.1007/s10029-014-1326-5

42. Mouravas V, Sfoungaris D. The etiology of indirect inguinal hernia in adults: congenital, acquired or both? Hernia (2015) 19:1037-8. doi:10.1007/ s10029-015-1365-6

43. Smith PG, Venkataraman P, Reddy H. Smooth muscle growth in the mature rat: role of sympathetic innervation. J Auton Nerv Syst (1990) 31:13-20. doi:10.1016/0165-1838(90)90167-H

44. Chamley JH, Campbell GR, Burnstock G. Dedifferentiation, redifferentiation and bundle formation of smooth muscle cells in tissue culture: the influence of cell number and nerve fibres. J Embryol Exp Morphol (1974) 32: 297-323.

45. Hutson JM, Hasthorpe S, Heyns CF. Anatomical and functional aspects of testicular descent and cryptorchidism. Endocr Rev (1997) 18:259-80. doi:10.1210/er.18.2.259

46. Stoker M, Gherardi E, Perryman M, Gray J. Scatter factor is a fibroblast-derived modulator of epithelial cell mobility. Nature (1987) 327:239-42. doi:10.1038/327239a0

47. Skibinski G, Skibinska A, James K. The role of hepatocyte growth factor and its receptor c-met in interactions between lymphocytes and stromal cells in secondary human lymphoid organs. Immunology (2001) 102:506-14 doi:10.1046/j.1365-2567.2001.01186.x 
48. Mousavi SA, Larijani LV, Mousavi SJ, Kenari SA, Darvish A. The role of transforming growth factor beta 1 in communicating and non-communicating hydrocele. Hernia (2016) 20:589-92. doi:10.1007/s10029-016-1492-8

49. Hutson JM, Temelcos C. Could inguinal hernia be treated medically? Med Hypotheses (2005) 64:37-40. doi:10.1016/j.mehy.2003.11.046

50. Henriksen NA, Yadete DH, Sorensen LT, Agren MS, Jorgensen LN. Connective tissue alteration in abdominal wall hernia. Br J Surg (2011) 98:210-9. doi:10.1002/bjs.7339

51. Szczesny W, Cerkaska K, Tretyn A, Dabrowiecki S. Etiology of inguinal hernia: ultrastructure of rectus sheath revisited. Hernia (2006) 10:266-71. doi:10.1007/s10029-006-0081-7

52. Peeters E, De Hertogh G, Junge K, Klinge U, Miserez M. Skin as marker for collagen type I/III ratio in abdominal wall fascia. Hernia (2014) 18:519-25. doi:10.1007/s10029-013-1128-1

53. Aren A, Gokce AH, Gokce FS, Dursun N. Roles of matrix metalloproteinases in the etiology of inguinal hernia. Hernia (2011) 15:667-71. doi:10.1007/ s10029-011-0846-5

54. Ozdemir S, Ozis ES, Gulpinar K, Aydin SM, Eren AA, Demirtas S, et al. The value of copper and zinc levels in hernia formation. Eur J Clin Invest (2011) 41:285-90. doi:10.1111/j.1365-2362.2010.02406.x

55. Klinge U, Zheng H, Si Z, Schumpelick V, Bhardwaj RS, Muys L, et al. Expression of the extracellular matrix proteins collagen I, collagen III and fibronectin and matrix metalloproteinase- 1 and -13 in the skin of patients with inguinal hernia. Eur Surg Res (1999) 31:480-90. doi:10.1159/000008728

56. Henriksen NA, Mortensen JH, Sorensen LT, Bay-Jensen AC, Agren MS, Jorgensen LN, et al. The collagen turnover profile is altered in patients with inguinal and incisional hernia. Surgery (2015) 157:312-21. doi:10.1016/j. surg.2014.09.006

57. Rodrigues Junior AJ, Rodrigues CJ, da Cunha AC, Jin Y. Quantitative analysis of collagen and elastic fibers in the transversalis fascia in direct and indirect inguinal hernia. Rev Hosp Clin Fac Med Sao Paulo (2002) 57:265-70. doi:10.1590/S0041-87812002000600004

58. Read RC. Inguinal herniation in the adult, defect or disease: a surgeon's odyssey. Hernia (2004) 8:296-9. doi:10.1007/s10029-004-0261-2

59. Pascual G, Rodriguez M, Mecham RP, Sommer P, Bujan J, Bellon JM. Lysyl oxidase like-1 dysregulation and its contribution to direct inguinal hernia. Eur J Clin Invest (2009) 39:328-37. doi:10.1111/j.1365-2362.2009. 02099.x

60. Bellon JM, Bajo A, Ga-Honduvilla N, Gimeno MJ, Pascual G, Guerrero A, et al. Fibroblasts from the transversalis fascia of young patients with direct inguinal hernias show constitutive MMP-2 overexpression. Ann Surg (2001) 233:287-91. doi:10.1097/00000658-200102000-00020

61. Bellon JM, Bujan J, Honduvilla NG, Jurado F, Gimeno MJ, Turnay J, et al. Study of biochemical substrate and role of metalloproteinases in fascia transversalis from hernial processes. Eur J Clin Invest (1997) 27:510-6. doi:10.1046/j.1365-2362.1997.1400686.x

62. Yamauchi M, Sricholpech M. Lysine post-translational modifications of collagen. Essays Biochem (2012) 52:113-33. doi:10.1042/bse0520113

63. Meyer AL, Berger E, Monteiro O Jr, Alonso PA, Stavale JN, Gonçalves MP. Quantitative and qualitative analysis of collagen types in the fascia transversalis of inguinalhernia patients. Arq Gastroenterol (2007) 44:230-4.

64. Casanova AB, Trindade EN, Trindade MR. Collagen in the transversalis fascia of patients with indirect inguinal hernia: a case-control study. Am J Surg (2009) 198:1-5. doi:10.1016/j.amjsurg.2008.07.021

65. Pans A, Albert A, Lapiere CM, Nusgens B. Biochemical study of collagen in adult groin hernias. J Surg Res (2001) 95:107-13. doi:10.1006/jsre.2000. 6024

66. Hosgor M, Karaca I, Ozer E, Suzek D, Ulukus C, Ozdamar A. Do alterations in collagen synthesis play an etiologic role in childhood inguinoscrotal pathologies: an immunohistochemical study. J Pediatr Surg (2004) 39:1024-9. doi:10.1016/j.jpedsurg.2004.03.058

67. Taniguchi S, Ueda K, Inoue T, Li TS, Kuga T, Hamano K. Impact of collagen subtype proportions in peritoneal tissues on inguinal hernia formation in adults and infants. Pediatr Surg Int (2006) 22:600-4. doi:10.1007/ s00383-006-1701-0

68. Henkel W, Glanville RW. Covalent crosslinking between molecules of type I and type III collagen. The involvement of the $\mathrm{N}$-terminal, nonhelical regions of the alpha 1 (I) and alpha 1 (III) chains in the formation of intermolecular crosslinks. Eur J Biochem (1982) 122:205-13. doi:10.1111/j.1432-1033.1982. tb05868.x

69. Shoulders MD, Raines RT. Collagen structure and stability. Annu Rev Biochem (2009) 78:929-58. doi:10.1146/annurev.biochem.77.032207.120833

70. Ricard-Blum S. The collagen family. Cold Spring Harb Perspect Biol (2011) 3:a004978. doi:10.1101/cshperspect.a004978

71. Ushiki T. Collagen fibers, reticular fibers and elastic fibers. A comprehensive understanding from a morphological viewpoint. Arch Histol Cytol (2002) 65:109-26. doi:10.1679/aohc.65.109

72. Mao M, Alavi MV, Labelle-Dumais C, Gould DB. Type IV collagens and basement membrane diseases: cell biology and pathogenic mechanisms. Curr Top Membr (2015) 76:61-116. doi:10.1016/bs.ctm.2015.09.002

73. Sun M, Chen S, Adams SM, Florer JB, Liu H, Kao WW, et al. Collagen V is a dominant regulator of collagen fibrillogenesis: dysfunctional regulation of structure and function in a corneal-stroma-specific Col5a1-null mouse model. J Cell Sci (2011) 124:4096-105. doi:10.1242/jcs.091363

74. Martin P, Teodoro WR, Velosa AP, de Morais J, Carrasco S, Christmann $\mathrm{RB}$, et al. Abnormal collagen $\mathrm{V}$ deposition in dermis correlates with skin thickening and disease activity in systemic sclerosis. Autoimmun Rev (2012) 11:827-35. doi:10.1016/j.autrev.2012.02.017

75. Wagenseil JE, Mecham RP. New insights into elastic fiber assembly. Birth Defects Res C Embryo Today (2007) 81:229-40. doi:10.1002/bdrc.20111

76. Khasigov PZ, Podobed OV, Ktzoeva SA, Gatagonova TM, Grachev SV, Shishkin SS, et al. Matrix metalloproteinases of normal human tissues. Biochemistry (Mosc) (2001) 66:130-40. doi:10.1023/A:1002879128392

77. Yu AE, Hewitt RE, Connor EW, Stetler-Stevenson WG. Matrix metalloproteinases. Novel targets for directed cancer therapy. Drugs Aging (1997) 11:229-44. doi:10.2165/00002512-199711030-00006

78. Kureshi A, Vaiude P, Nazhat SN, Petrie A, Brown RA. Matrix mechanical properties of transversalis fascia in inguinal herniation as a model for tissue expansion. J Biomech (2008) 41:3462-8. doi:10.1016/j.jbiomech.2008. 08.018

79. Pascual G, Corrales C, Gomez-Gil V, Bujan J, Bellon JM. TGF-betal overexpression in the transversalis fascia of patients with direct inguinal hernia. Eur J Clin Invest (2007) 37:516-21. doi:10.1111/j.1365-2362.2007.01816.x

80. Kayaoglu HA, Hazinedaroglu SM, Bulent Erkek A, Kocaturk PA, Kavas GO, Aribal D. Comparison of the plasma and hernia sac tissue copper levels in direct and indirect inguinal hernia patients. Biol Trace Elem Res (2005) 108:53-9. doi:10.1385/BTER:108:1-3:053

81. Pascual G, Rodriguez M, Gomez-Gil V, Trejo C, Bujan J, Bellon JM. Active matrix metalloproteinase-2 upregulation in the abdominal skin of patients with direct inguinal hernia. Eur J Clin Invest (2010) 40:1113-21. doi:10.1111/j.1365-2362.2010.02364.x

82. Burcharth J, Pommergaard HC, Rosenberg J. The inheritance of groin hernia: a systematic review. Hernia (2013) 17:183-9. doi:10.1007/s10029-013-1060-4

83. Zoller B, Ji J, Sundquist J, Sundquist K. Shared and nonshared familial susceptibility to surgically treated inguinal hernia, femoral hernia, incisional hernia, epigastric hernia, and umbilical hernia. J Am Coll Surg (2013) 217:289-99.e1. doi:10.1016/j.jamcollsurg.2013.04.020

84. Burcharth J, Pedersen M, Bisgaard T, Pedersen CB, Rosenberg J. Familial clustering and risk of groin hernia in children. BJS Open (2017) 1:46-9. doi: $10.1002 /$ bjs5.8

85. Mihailov E, Nikopensius T, Reigo A, Nikkolo C, Kals M, Aruaas K, et al. Whole-exome sequencing identifies a potential TTN mutation in a multiplex family with inguinal hernia. Hernia (2017) 21:95-100. doi:10.1007/ s10029-016-1491-9

86. Zhang Y, Han Q, Li C, Li W, Fan H, Xing Q, et al. Genetic analysis of the TBX1 gene promoter in indirect inguinal hernia. Gene (2014) 535:290-3. doi:10.1016/j.gene.2013.11.012

87. Qiao Y, Zhang Z, Huang W, Pang S, Xing Q, Yan B. Two functional sequence variants of the GATA6 gene promoter in patients with indirect inguinal hernia. Gene (2014) 547:86-90. doi:10.1016/j.gene.2014.06.030

88. Zhao Z, Tian W, Wang L, Wang H, Qin X, Xing Q, et al. Genetic and functional analysis of the TBX3 gene promoter in indirect inguinal hernia. Gene (2015) 554:101-4. doi:10.1016/j.gene.2014.10.031

89. Sezer S, Simsek N, Celik HT, Erden G, Ozturk G, Duzgun AP, et al. Association of collagen type I alpha 1 gene polymorphism with inguinal hernia. Hernia (2014) 18:507-12. doi:10.1007/s10029-013-1147-y 
90. Jorgenson E, Makki N, Shen L, Chen DC, Tian C, Eckalbar WL, et al. A genome-wide association study identifies four novel susceptibility loci underlying inguinal hernia. Nat Commun (2015) 6:10130. doi:10.1038/ ncomms 10130

91. Poobalan AS, Bruce J, Smith WC, King PM, Krukowski ZH, Chambers WA. A review of chronic pain after inguinal herniorrhaphy. Clin J Pain (2003) 19:48-54. doi:10.1097/00002508-200301000-00006

92. Aasvang E, Kehlet H. Chronic postoperative pain: the case of inguinal herniorrhaphy. Br J Anaesth (2005) 95:69-76. doi:10.1093/bja/aei019

93. Scheuermann U, Niebisch S, Lyros O, Jansen-Winkeln B, Gockel I. Transabdominal preperitoneal (TAPP) versus Lichtenstein operation for primary inguinal herniarepair - a systematic review and meta-analysis of randomized controlled trials. BMC Surg (2017) 10(17):55. doi:10.1186/ s12893-017-0253-7

94. Simons MP, Aufenacker T, Bay-Nielsen M, Bouillot JL, Campanelli G, Conze J, et al. European Hernia Society guidelines on the treatment of inguinal hernia in adult patients. Hernia (2009) 13:343-403. doi:10.1007/s10029-009-0529-7

95. Miserez M, Peeters E, Aufenacker T, Bouillot JL, Campanelli G, Conze J, et al. Update with level 1 studies of the European Hernia Society guidelines on the treatment of inguinal hernia in adult patients. Hernia (2014) 18:151-63. doi:10.1007/s10029-014-1236-6

96. Schleidgen S, Klingler C, Bertram T, Rogowski WH, Marckmann G. What is personalized medicine: sharpening a vague term based on a systematic literature review. BMC Med Ethics (2013) 21(14):55. doi:10.1186/1472-6939-14-55

97. Öberg S, Andresen K, Rosenberg J. Absorbable meshes in inguinal hernia surgery: a systematic review and meta-analysis. Surg Innov (2017) 24:289-98. doi:10.1177/1553350617697849

98. Fang Z, Ren F, Zhou J, Tian J. Biologic mesh versus synthetic mesh in open inguinal hernia repair: system review and meta-analysis. ANZ J Surg (2015) 85:910-6. doi:10.1111/ans.13234

99. Rosenberg J, Bisgaard T, Kehlet H, Wara P, Asmussen T, Juul P, et al. Danish Hernia Database recommendations for the management of inguinal and femoral hernia in adults. Dan Med Bull (2011) 58:C4243.
100. Bay-Nielsen M, Perkins FM, Kehlet H. Pain and functional impairment 1 year after inguinal herniorrhaphy: a nationwide questionnaire study. Ann Surg (2001) 233:1-7. doi:10.1097/00000658-200101000-00001

101. Langeveld HR, Klitsie P, Smedinga H, Eker H, Van't Riet M, Weidema W, et al. Prognostic value of age for chronic postoperative inguinal pain. Hernia (2015) 19:549-55. doi:10.1007/s10029-014-1282-0

102. Haastrup E, Andresen K, Rosenberg J. Low reoperation rates in young males after sutured repair of indirect inguinal hernia: arguments for a tailored approach. Am J Surg (Forthcoming 2017). doi:10.1016/ j.amjsurg.2017.02.015

103. Klinger A, Kawata M, Villalobos M, Jones RB, Pike S, Wu N, et al. Living scaffolds: surgical repair using scaffolds seeded with human adipose-derived stem cells. Hernia (2016) 20:161-70. doi:10.1007/s10029-0151415-0

104. Iyyanki TS, Dunne LW, Zhang Q, Hubenak J, Turza KC, Butler CE. Adiposederived stem-cell-seeded non-cross-linked porcine acellular dermal matrix increases cellular infiltration, vascular infiltration, and mechanical strength of ventral hernia repairs. Tissue Eng Part A (2015) 21:475-85. doi:10.1089/ ten.TEA.2014.0235

105. Zheng R, Altieri MS, Yang J, Chen H, Pryor AD, Bates A, et al. Long-term incidence of contralateral primary hernia repair following unilateral inguinal hernia repair in a cohort of 32,834 patients. Surg Endosc (2017) 31:817-22. doi:10.1007/s00464-016-5037-0

Conflict of Interest Statement: SÖ reports no potential conflicts of interest. KA reports personal fees from Bard outside the submitted work. JR reports personal fees from Bard and Merck, outside the submitted work.

Copyright (c) 2017 Öberg, Andresen and Rosenberg. This is an open-access article distributed under the terms of the Creative Commons Attribution License (CC BY). The use, distribution or reproduction in other forums is permitted, provided the original author(s) or licensor are credited and that the original publication in this journal is cited, in accordance with accepted academic practice. No use, distribution or reproduction is permitted which does not comply with these terms. 